\title{
Primary Intraosseous Squamous Cell Carcinoma Arising from Keratocystic Odontogenic Tumor
}

Shanmukha Ramya*, Sumit Majumdar, Divya Uppala and Nagahimabindu Vennamaneni

GITAM Dental College and Hospital, Visakhapatnam, Andhra Pradesh, India

*Corresponding author: Shanmukha Ramya, Department of Oral Pathology, GITAM Dental College and Hospital, Gandhi Nagar Campus-530045, Visakhapatnam, Andhra Pradesh, India, Tel: 919948581250, 09492343142; Fax: +358 10773 2099; E-mail: rams.cutiepie@gmail.com

Received date: Aug 14, 2015, Accepted date: Sep 25, 2015, Publication date: Sep 28, 2015

Copyright: @ 2015 Ramya S, et al. This is an open-access article distributed under the terms of the Creative Commons Attribution License; which permits unrestricted use; distribution; and reproduction in any medium; provided the original author and source are credited.

Abstract
Primary intraosseous squamous cell carcinoma (PIOSCC) developing from a Keratocystic odontogenic tumor
(KCOT) is a rare malignant neoplasm of the jaws. The incidence of carcinomas arising in odontogenic cysts are less.
This article presents a case of PIOSCC of the mandible developing from a KCOT in a 35-year-old male patient.

Keywords: OKC; Malignant transformation; Mandible; Intra osseous carcinoma

\section{Introduction}

Carcinoma arising from the wall of an odontogenic cyst is an extremely rare condition which is essentially limited to the jaws [1]. Carcinomas can arise from long standing radicular cyst, residual cyst, dentigerous cyst, keratocystic odontogenic tumor, lateral periodontal cyst, and calcifying odontogenic cyst [2]. The incidence rate is approximately 1-2 per1000 [3]. This article presents a case of a PIOSCC arising from a pre-existing KCOT in the posterior mandible.

\section{Case Report}

A 35-year old male patient visited outpatient department of GITAM Dental College and hospital, with a chief complaint of swelling in the left lower back tooth region since 1 year. Past dental history revealed that patient visited a private hospital for the same complaint 1 month back. An incisional biopsy was performed and a diagnosis of KCOT was given.

Extra-oral examination revealed a swelling on the left lower one third of the face near the inferior border of mandible. Lymph nodes were not palpable. Intraoral examination showed an oval, non-tender swelling which was firm to hard in consistency and measuring about 2 $\times 1 \mathrm{~cm}$ in size extending from distal surface of attached gingiva irt 34 to mesial surface of 37 (Figure 1).

OrthoPantamoGraph (OPG) revealed well defined multilocular radiolucencies extending from 35 to ascending ramus of mandible involving the inferior border of mandible on left side. A single well defined unilocular lesion extending from 33 to 43 regions was also evident (Figure 2).

Fine Needle Aspiration Cytology was performed. The aspirated fluid was yellowish red in color and viscous in nature. The cytology showed mixed inflammatory cell infiltrate and desquamated cells.

Cyst enucleation and peripheral ostectomy was done and the specimen was received for histopathological investigation. Hematoxylin and eosin ( $\mathrm{H}$ and $\mathrm{E})$ stained soft tissue sections showed cystic lining epithelium with corrugated parakeratin layer and palisading basal layer demonstrating typical picket fence appearance (Figure 3). Whereas another part of the epithelium showed keratin pearls, dysplastic features like pleomorphism, increased mitotic activity, hyperchromatism. Epithelium showed discontinuity in the basement membrane with tumor cells invading into the connective tissue (Figure 4). Histopathological features were in favor of Squamous Cell Carcinoma. The final diagnosis of PIOSCC arising from KCOT was rendered. Patient was treated with Hemi mandibulectomy. Chest radiograph of the patient was normal. No recurrence was observed.

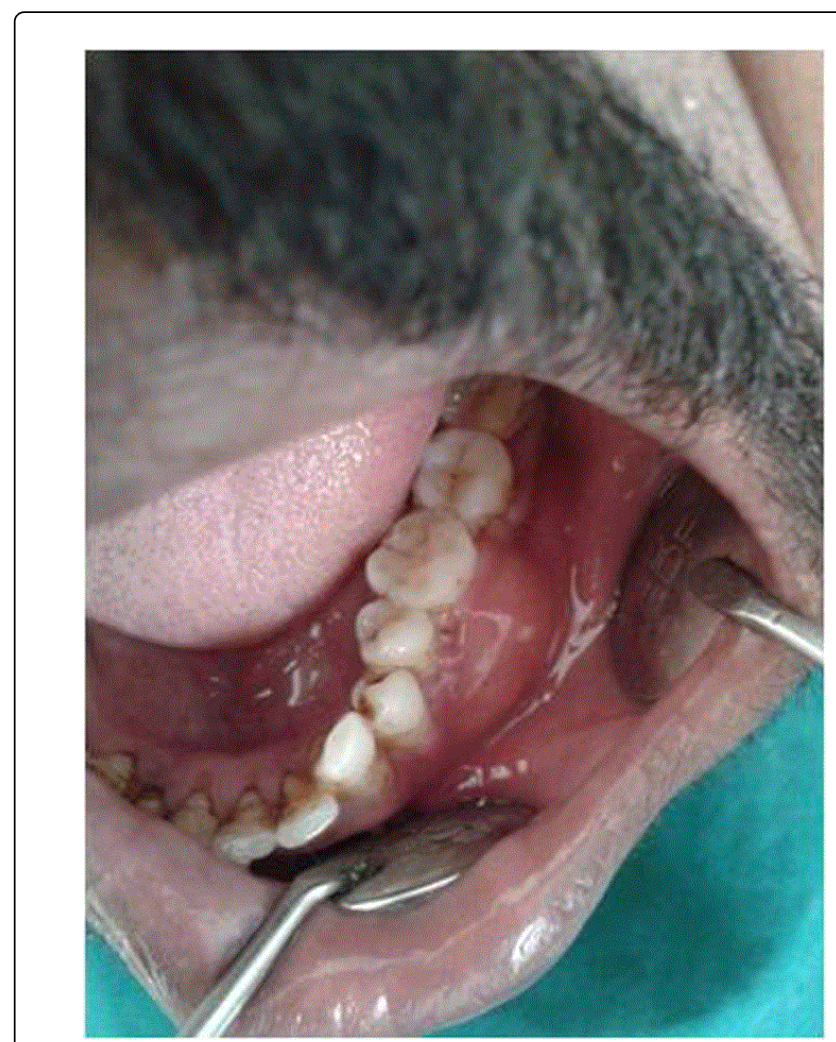

Figure 1: Intra oral examination shows a swelling irt 35 to 37. 
Citation: Ramya S, Majumdar S, Uppala D, Vennamaneni N (2015) Primary Intraosseous Squamous Cell Carcinoma Arising from Keratocystic Odontogenic Tumor. J Nucl Med Radiat Ther 6: 253. doi:10.4172/2155-9619.1000253

Page 2 of 3

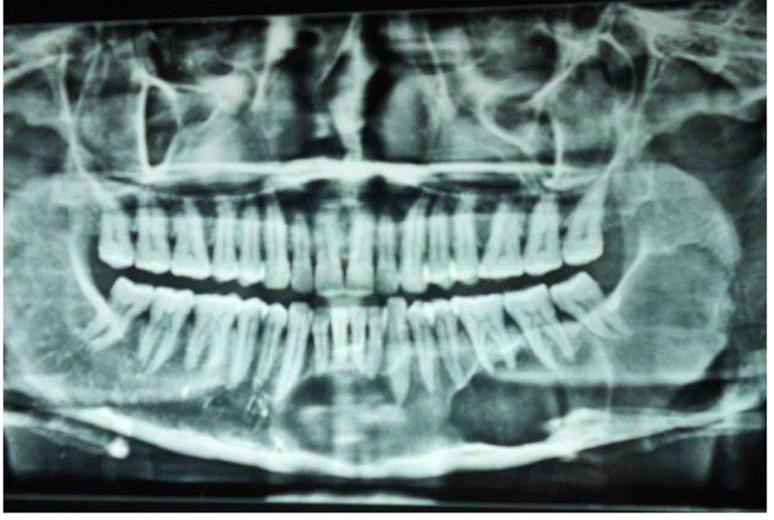

Figure 2: The OPG reveals multilocular radiolucencies extending from 35 to ascending ramus of mandible with an unilocular lesion extending from 33 to 43 .

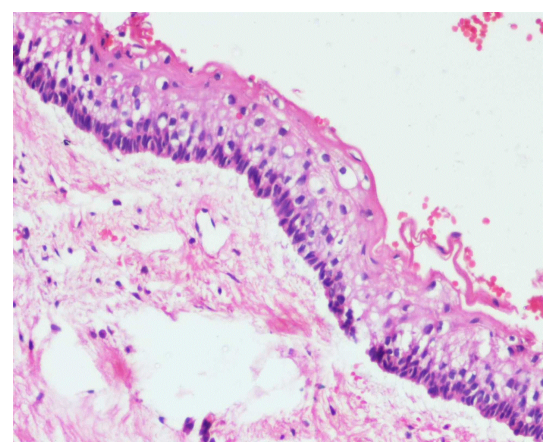

Figure 3: Cystic lining shows typical KCOT features. (HandE stain, 10x view).

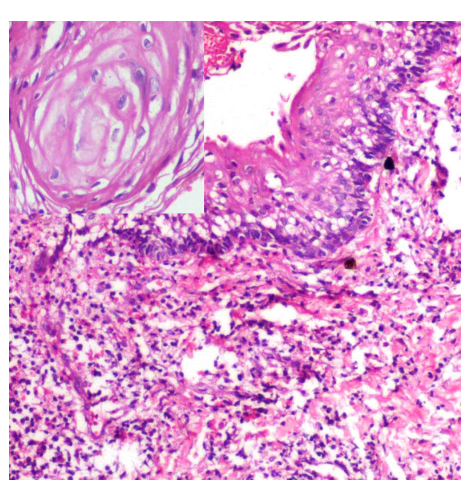

Figure 4: Breach in basement membrane with invasion of tumor cells into the connective tissue. Inset showing Keratin pearl formation. ( $\mathrm{H}$ and $\mathrm{E}$ stain, 20x view).

\section{Discussion}

Carcinomatous involvement of the jaws is usually the result of direct extension from adjacent structures. Occasionally, tumors in distant sites metastasize to the jaws. Primary carcinomas arising within the jaws from enclaved epithelium or from the lining of odontogenic cysts are uncommon [4].

Suei et al. proposed 3 criteria for the diagnosis of PIOSCC [5].

1. Ulcer should be absent on the overlying mucosa except that due to causes such as trauma or tooth extraction to demarcate it from SCC of surface mucosal origin.

2. Serial sections of histological specimens must demonstrate SCC without cystic component or other odontogenic tumor cells to rule out the possibility of another odontogenic carcinoma.

3. At the time of diagnosis, the chest radiograph must be clear and for a follow-up period of more than 6 months to rule out the metastasis from a distant primary tumor.

PIOSCC arising from an Odontogenic Keratocyst shows a wide age range, with 57 years mean age with Male: Female ratio 2:1. PIOSCC, predominant site of occurrence is in the mandible $79 \%$ as compared to maxilla $21 \%[6$.

The pathogenesis of PIOSCC arising from an OKC is unclear. Browne et al. suggested that odontogenic cysts with keratinization may have greater tendency to undergo malignant transformation than nonkeratinizing cysts [7]. Long-standing chronic inflammation has been suggested as a possible predisposing factor by Bernard Tan et al. [8].

Five year survival rate is ranging from $30 \%$ to $40 \%$ depicting it's relatively poor prognosis [9].

Surgery alone or combined therapy of surgery and radiation is the most common approach [10].

\section{Conclusion}

The clinical and radiographic features of carcinoma arising in an odontogenic cyst are non-specific, hence it may be difficult to distinguish between a simple odontogenic cyst and a malignant tumor. Incisional biopsy may not often represent the entire lesion. The true nature of an odontogenic cyst and its malignant transformation are typically revealed after surgical resection and meticulous histopathological evaluation of the entire lesion. Therefore, we should be aware of the potential for malignant transformation in odontogenic cysts.

\section{References}

1. Punnya A, Kumar GS, Rekha K, Vandana R (2004) Primary intraosseous odontogenic carcinoma with osteoid/dentinoid formation. J Oral Pathol Med 33: 121-124.

2. Neville BW, Damm DD, Allen CM, Bouquot JE (2009) Oral and Maxillofacial Pathology. (3rdedn) WB Saunders: 700-701.

3. Tamgadge S, Tamgadge A, Modak N, Bhalerao S (2013) Primary intraosseous squamous cell carcinoma arising from an odontogenic keratocyst: a case report and literature review. Ecancermedicalscience 7: 316.

4. Yu JJ, Hwan EH, Lee SR, Choi JH (2003) Squamous cell carcinoma arising in an odontogenic cyst. Korean J Oral Maxillofac Radiol 33: 235-238.

5. Suei Y, Tanimoto K, Taguchi A, Wada T (1994) Primary intraosseous carcinoma: review of the literature and diagnostic criteria. J Oral Maxillofac Surg 52: 580-583.

6. Bodner L, Manor E, Shear M, van der Waal I (2011) Primary intraosseous squamous cell carcinoma arising in an odontogenic cyst: a clinicopathologic analysis of 116 reported cases. J Oral Pathol Med 40: 733-738. 
Citation: Ramya S, Majumdar S, Uppala D, Vennamaneni N (2015) Primary Intraosseous Squamous Cell Carcinoma Arising from Keratocystic Odontogenic Tumor. J Nucl Med Radiat Ther 6: 253. doi:10.4172/2155-9619.1000253

Page 3 of 3

7. Browne RM, Gough NG (1972) Mlignnt chnge in the epithelium lining odontogenic cysts. Cancer 29: 1199-1207.

8. Tan B, Yan TS, Shermin L, Teck KC, Yoke PC, et al. (2013) Malignant transformation of keratocystic odontogenic tumor: two case reports. Am J Otolaryngol 34: 357-361.

9. Thomas G, Pandey M, Mathew A, Abraham EK, Francis A, et al. (2001) Primary intraosseous carcinoma of the jaw: pooled analysis of world literature and report of two new cases. Int J Oral Maxillofac Surg 30: 349-355

10. Chaisuparat R, Coletti D, Kolokythas A, Ord RA, Nikitakis NG (2006) Primary intraosseous odontogenic carcinoma arising in an odontogenic cyst or de novo: a clinicopathologic study of six new cases. Oral Surg Oral Med Oral Pathol Oral Radiol Endod 101: 194-200. 